\title{
COMPARATIVE RESEARCH
}

https://doi.org/10.15407/econlaw.2020.03.034

УДК 346.9

В.О. КОВЕРЗНЕВ, д-р юрид. наук, доцент, старш. наук. співроб.

Державна установа «Інститут економіко-правових досліджень

імені В.К. Мамутова НАН України», м. Київ, Україна

(iD) orcid.org/0000-0003-0985-3838

\section{МІЖНАРОДНІ СТАНДАРТИ ЗАБЕЗПЕЧЕННЯ ПРАВА ДОСТУПУ ДО СУДУ УЧАСНИКАМ ЕКОНОМІЧНИХ ВІДНОСИН}

\begin{abstract}
Ключові слова: доступ до суду, правосуддя, верховенство права, захист прав особи.
\end{abstract}

Проаналізовано міжнародні правові акти та рішення Європейського суду з прав людини, у яких сформульовано стандарти забезпечення усім особам права доступу до суду. На підставі проведеного дослідження визначено основні критерії, дотримання яких гарантує належний доступ до суду та ефективний захист порушених прав учасників економічних відносин, розкрито сутність цих критерїв.

Постановка проблеми. 25.09.2015 Генеральна Асамблея Організації Об’єднаних Націй ухвалила Резолюцію «Перетворення нашого світу: Порядок денний у сфері сталого розвитку до 2030 року», якою затвердила новий порядок денний для всіх людей планети задля подальшого процвітання (далі Порядок денний).

Порядок денний підлягає реалізації усіма країнами світу, що прагнуть розвиватися на засадах співробітництва і партнерства; він містить 17 цілей і 169 завдань, орієнтованих на подолання бідності, побудову миролюбного та справедливого суспільства, подальшу реалізацію прав людини, досягнення гендерної рівності, водночас має комплексний і неподільний характер.

У Порядку денному намічені цілі та завдання на наступні 15 років, що спрямовані на стимулювання діяльності у тих сферах, які є критично значущими для всього людства і планети; відмічено, що сучасний світ повинен йти шляхом забезпечення всезагальної поваги до прав людини та людської гідності, верховенства права, справедливості, рівності і недискримінації, що дає змогу розкрити людський потенціал і сприяє процвітанню усього людства; визнано необхідність побудови миролюбного, справедливого і всеохопного суспільства, у якому забезпечено рівний доступ до правосуддя, що грунтується на повазі прав людини, верховенстві права і належному врядуванні на всіх рівнях, а також на прозорих, ефективних і підзвітних інституціях; визначено фактори, що спричиняють насильство, не-

Ц и ту в ан н я: Коверзнев В.О. Міжнародні стандарти забезпечення права доступу до суду учасникам економічних відносин. Економіка та право. 2020, № 3. C. 34-42. https://doi.org/10.15407/econlaw.2020.03.034 
захищеність і несправедливість, як-от: нерівність, корупція, неякісне врядування та незаконні фінансові потоки і потоки зброї.

Шістнадцята ціль Порядку денного присвячена забезпеченню усім доступу до правосуддя та створенню ефективних і підзвітних інституцій на всіх рівнях. Досягнення цієї цілі Порядку денного передбачено шляхом:

- сприяння верховенству права на національному та міжнародному рівнях і забезпечення усім суб'єктам приватного права рівного доступу до правосуддя;

- істотного скорочення масштабів корупції та хабарництва в усіх формах їхнього прояву;

- створення ефективних, підзвітних і прозорих установ на всіх рівнях;

- забезпечення доступу громадськості до інформації та захисту основних свобод відповідно до національного законодавства і міжнародних угод;

- заохочення недискримінаційних законів і політики щодо сталого розвитку та забезпечення їх дотримання.

Порядок денний, включно із Цілями сталого розвитку, підлягає виконанню у рамках оновленого Глобального партнерства держав в інтересах сталого розвитку, в основі якого лежатимуть узгоджені стратегії сталого розвитку, побудовані на засадах національної співпричетності та підтримувані комплексними національними механізмами фінансування [1].

На виконання міжнародних зобов'язань, що випливають із Порядку денного, 15.09.2017 Міністерство економічного розвитку України представило Національну доповідь «Цілі сталого розвитку: Україна», яка визначає базові показники для досягнення Цілей сталого розвитку (далі ЦСР).

ЦСР характеризуються за чотирма напрямами: 1) справедливий соціальний розвиток, спрямований на розв'язання таких проблем, як подолання бідності і соціальної нерівності, гарантування безпеки населення, покращення медичного обслуговування та якості життя загалом; 2) стале економічне зростання та зайнятість населення, спрямоване на реальне підвищення внутрішнього валового продукту, створення нових робочих місць і зменшення рівня безробіття; 3 ) підвищення ефективності діяльності органів державної влади та органів місцевого самоврядування, забезпечення прозорості ухвалення ними управлінських рі- шень та громадського контролю за виконанням ними своїх функцій; 4) екологічна рівновага та розбудова стійкості з метою забезпечення раціонального використання лісових, водних і земельних ресурсів, переробки та утилізації відходів.

Суспільне бачення розвитку України до 2030 року охоплює такі орієнтири: добробут і здоров'я населення, що забезпечуватимуться $i н-$ новаційним розвитком економіки, побудованим на сталому використанні природних ресурсів. У структурі експорту передбачено зміни, спрямовані на перехід від експорту сировини та продуктів первинної переробки до продуктів та послуг з високим ступенем доданої вартості.

У доповіді Уряду України представлені результати адаптації 17 глобальних ЦСР з урахуванням специфіки національного розвитку, серед яких - забезпечення для усіх відносин рівного доступу до правосуддя; визначено індикатори досягнення цієї цілі - підвищення рівня довіри громадян до суду до 2030 р. до $55 \%$ та забезпечення рівного доступу до правосуддя, а також підвищення рівня обізнаності громадян щодо прав на безоплатну правову допомогу до 2030 р. до $90 \%$ [2].

Таким чином, перетворення і сталий розвиток сучасних країн світу, у тому числі й України, не уявляється без забезпечення для усіх учасників економічних (господарських) відносин рівного доступу до суду і правосуддя, яке повинно грунтуватися на повазі до основоположних прав, пануванні в суспільстві верховенства права, прозорій діяльності судів та ефективному здійсненню ними правосуддя, гарантування громадськості доступу до інформації про діяльність судів.

Аналіз останніх досліджень і публікацій. Проблематика забезпечення учасникам економічних відносин вільного доступу до суду дотепер залишається поза увагою представників науки господарського права. $E$ окремі роботи В.В. Городовенко, Г.В. Фазикош, Т.І. Фулей, які присвячені загальному аналізу рішень Європейського суду з прав людини, що зумовлює актуальність обраної теми дослідження.

Цією статтею розпочинається цикл публікацій, присвячених різним аспектам доступу до інституційних форм захисту прав учасників економічних відносин як передумови сталого розвитку України. 
Виклад основного матеріалу. У міжнародноправових актах, які визначають базові стандарти здійснення правосуддя, доступ до правосуддя розглядається через призму забезпечення особі можливості безперешкодного звернення до суду та ефективного захисту порушених прав у стислі терміни.

Зокрема, Загальна декларація прав людини 1948 року гарантує рівність усіх перед законом, без будь-яких відмінностей, рівний захист усіх від дискримінації, ефективне поновлення у правах національними судами у випадках порушення його основних прав, представлених конституцією або законами [3].

У ст. 14 Міжнародного пакту про громадянські й політичні права 1966 року встановлено, що всі особи рівні перед судами і трибуналами; у разі визначення прав і обов'язків у будь-якому цивільному процесі кожен має право на справедливий і публічний розгляд справи компетентним, незалежним і безстороннім судом, створеним на підставі закону. Преса і публіка можуть не допускатися на весь судовий розгляд або частину його з міркувань моралі, громадського порядку чи державної безпеки у демократичному суспільстві, або коли того вимагають інтереси приватного життя сторін, або - тією мірою, в якій як це, на думку суду, є строго необхідним, - за особливих обставин, коли публічність порушувала б інтереси правосуддя; однак будь-яка судова постанова в цивільній справі повинна бути публічною, за винятком тих випадків, коли інтереси неповнолітніх вимагають іншого чи коли справа стосується матримоніальних спорів або опіки над дітьми [4].

Варто відзначити, що ст. 14 Міжнародного пакту про громадянські й політичні права 1966 року поширюється не лише на класичні цивільні спори, а також на спори, що виникають у сфері господарювання та віднесені в Україні до юрисдикції господарських судів.

На європейському континенті особливе значення відіграє Конвенція про захист прав людини і основоположних свобод 1950 року (далі Конвенція), яка була ухвалена з метою запобігання неналежному, а часто й жорстокому поводженню з людиною, що набуло значного поширення в Європі особливо під час Другої світової війни 1939-1945 рр. Конвенція запроваджує мінімальні стандарти прав людини, які забезпечують гідне життя, водночас є до- роговказом для іiі договірних сторін у процесі формування власних національні стандартів.

Конвенція ратифікована Законом України від 17.07.1997 № 475/97-ВР, а тому є частиною національного законодавства України.

У питаннях тлумачення норм Конвенції, що мають загальний характер, особливе значення має практика Європейського суду з прав людини (далі ЄСПЛ), оскільки саме у рішеннях цього Суду розкривається зміст положень Конвенції в контексті конкретних правовідносин.

За приписом ст. 13 Закону України «Про виконання рішень та застосування практики Свропейського суду з прав людини» від 23.02.2006 № 3477-IV з метою усунення зазначеної в рішенні Суду системної проблеми та її першопричини застосовуються заходи загального характеру, а саме: внесення змін до чинного законодавства та практики його застосування; внесення змін до адміністративної практики; забезпечення юридичної експертизи проєктів; забезпечення професійної підготовки 3 питань вивчення конвенції та практики Суду для всіх категорій осіб, професійна діяльність яких пов'язана із застосуванням норм права та триманням людей в умовах позбавлення волі.

Згідно зі ст. 17 Закону України «Про виконання рішень та застосування практики $\mathrm{E}_{\text {в- }}$ ропейського суду з прав людини» суди України повинні застосовувати Конвенцію і практику ССПЛ як джерела права.

Право особи на доступу до суду закріплено у статті 6 Конвенції, згідно з якою кожному гарантовано право на справедливий і публічний розгляд справи упродовж розумного строку незалежним і безстороннім судом, встановленим законом, який вирішить спір щодо його права та обов'язків цивільного характеру або встановить обгрунтованість будь-якого висунутого проти нього кримінального обвинувачення [5].

Як свідчить практика ЄСПЛ, гарантії ст. 6 Конвенції поширюються не лише на кримінальні справи та цивільні спори, але й на справи, що підлягають розгляду в порядку господарського судочинства. Для визначення змісту правової конструкції «цивільні права та обов'язки» ССПЛ застосовує принцип «автономного тлумачення» (тлумачення без прив'язки до національного законодавства держави), насамперед, як реальний спір, що стосується як самого права, так і його різновидів або 
моделей застосування (ухвала від 17.09.2002 щодо прийнятності заяви М. Марченка проти України, заява № 65520/01).

У справі «Феррадзіні проти Італії (2001) ЄСПЛ зробив висновок, що провадження у справі, які за національним правом класифікуються як частина «публічного права», можуть підпадати під сферу застосування «цивільної» частини ст. 6 Конвенції, якщо підсумок справи має вирішальне значення для приватних прав і обов'язків, коли йдеться, наприклад, про продаж землі, управління приватною клінікою, майнові інтереси, надання адміністративного дозволу стосовно умов професійної практики чи ліцензії на обслуговування алкогольними напоями.

Здійснюючи тлумачення правової категорії «справедливий судовий розгляд» в рішенні у справі «Альберт та Ле Конт проти Бельгії» (1983), ССПЛ вказав, що держави-члени під час розгляду цивільних справ наділені більшим рівнем свободи стосовно цивільних прав і обов'язків, ніж під час розгляду кримінальних справ.

У справі «Голдер проти Сполученого Королівства» (1975) ЄСПЛ наголосив на неможливості припускати, щоб ст. 6 Конвенції містила детальний опис наданих сторонам процесуальних гарантій у цивільних справах і не захищала би передусім те, що дає можливість практично користуватися цими гарантіями, доступу до суду; такі характеристики процесу як справедливість, публічність, динамізм, позбавляються смислу, якщо немає прямого судового розгляду. У цій справі виділяються юридичний і фактичний різновиди доступу до суду.

Виходячи із прецедентної практики ССПЛ, під юридичним доступом до суду слід розуміти наявність у національному законодавстві норм, які гарантують особі звернення до суду за захистом порушених, невизнаних або оспорюваних прав; фактичним доступом є реальне забезпечення права особи на безперешкодне звернення до суду, у разі виникнення такої потреби.

Зміст категорії «незалежний і неупереджений суд» ЄСПЛ розкриває в рішеннях, ухвалених у справах «Совтрансавто проти України» (2002), «Зубко та інші проти України» (2005), Сокуренко і Стригун проти України» (2006), «Білуха проти України» (2006), вказуючи на те, що неупередженість і безсторонність повинні розкриватися за суб'єктивним та об'єктивним критеріями.

Суб’єктивний критерій визначається, виходячи з особистих переконань і поведінки судді під час розгляду конкретної справи, а також у побуті. Саме дотримання суб'єктивного критерію напряму впливає на довіру громадськості до конкретного судді та судової системи загалом.

Об’єктивний критерій передбачає відсутність в учасників справи будь-яких сумнівів у безсторонності суду як державної інституції. Він залежить від способу утворення суду як органу правосуддя, наявності законодавчих гарантій незалежності судової гілки влади від законодавчої та виконавчої влади і глави держави, а також окремих політиків і впливових фінансово-промислових груп.

Дефініція «суд, встановлений законом» передбачає законність функціонування організаційної структуру судочинства і дотримання питань забезпечення юрисдикції певних категорій спорів (рішення у справі «Лео Занд проти Австрії» (1978)). Таким чином, формулювання «суд, встановлений законом» стосується не тільки правових засад судочинства, але й законності утворення складу суду під час вирішення конкретної справи.

Розумність строків тривалості судових проваджень оцінюється ЄСПЛ, виходячи з критеріїв складності справи, кількості учасників справи та їх поведінки в судовому процесі, а також предмета спору (справа «Смірнова проти України» (2006)).

Складність справи зумовлюється, насамперед, характером спору. Утім, на складність справи може впливати й потреба допиту значної кількості свідків, необхідність проведення судових експертиз і витребування додаткових доказів в інших осіб тошо.

Належність поведінки учасників справи підлягає оцінці з точки зору сумлінного використання учасниками своїх процесуальних прав та утримання від вчинення дій, які можуть бути розцінені як зловживання процесуальними правами, зокрема: ухилення від отримання повістки про виклик до суду, неявка до суду без поважних причин, свідоме подання безпідставних процесуальних заяв, як-от: про відвід судді; про оскарження проміжних процесуальних судових рішень, які не підлягають 
оскарженню, або неодноразове оскарження судового рішення, яке вже було предметом перегляду суду вищої інстанції; про витребування доказів, які не стосуються предмета спору, тощо.

Словосполучення «згідно із законом» передбачає відступ від механічного застосування національного законодавства держави i потребує оцінки якості національного закону в контексті його відповідності верховенству праву.

У справі «Мелоун проти Сполученого Королівства» ЕСПЛ сформулював критерії якості національного закону, зокрема, доступність закону, його передбачуваність, достатність чітко встановлювати межі дискреційних повноважень органів влади та спосіб їх здійснення. Так, Суд зазначив, що у законі повинні бути в достатньо чітких формулюваннях визначені обсяг і порядок здійснення владних повноважень з урахуванням законної мети кожної дії з тим, щоб забезпечити особі відповідний захист від незаконного втручання 3 боку держави.

У рішенні у справі «Толстой-Мілославський проти Сполученого Королівства» (1995) ССПЛ зазначив, що під терміном «закон» треба розуміти як норми, які встановлені писаним правом, так і правила, сформульовані у прецедентному праві. Закон має відповідати якісним вимогам, насамперед, вимогам доступності і передбачуваності, щоб громадянин мав змогу отримати адекватну інформацію про обставини застосування правових норм у конкретному випадку. Норма не може розглядатися як «закон», якщо вона не сформульована 3 достатньою чіткістю, коли громадянин не може самостійно визначитися, як регулювати свою поведінку за допомогою цієї норми.

Закон повинен пристосовуватися до обставин, що змінюються, до того ж необхідно уникати ситуації, коли багато законів викладені термінами, які є певною мірою неясними i тлумачення та застосування яких є питанням судової практики (рішення у справі «Санді Таймс проти Сполученого Королівства» (1979)).

Доволі значущим елементом верховенства права є принцип юридичної визначеності, в основі якого лежить принцип res judicata (лат. вирішена справа). За принципом res judicata остаточне рішення суду, яке вступило в законну силу, є обов'язковим для сторін і не може переглядатися. Так, у справі «Олександр Волков проти України» (2013) ЄСПЛ констатовано порушення принципу юридичної визначеності, з огляду на відсутність у процесуальному законодавстві України положень щодо строків давності притягнення судді до відповідальності за порушення присяги судді, в контексті вимог «якості закону».

Розгляд судами справ, у тому числі й господарських, повинен відбуватися на засадах змагальності та диспозитивності судового процесу. У рішеннях у справах «Руїз-Торіха проти Іспанії» (1994), «Кероярві проти Фінляндії» (1995), «Стрижак проти України» (2005) ЕСПЛ виклав позицію про те, що змагальність процесу передбачає надання кожній стороні рівних можливостей в ознайомленні з усіма доказами та поясненнями усіх учасників справи, а також праві відповісти на них; змагальність процесу повинна бути фактичною, а сторони рівними; суд не повинен ставити одну сторону у менш сприятливі умови порівняно з іншою стороною; учасники справи повинні мати рівні можливості в оскарженні рішення, водночас сторонні особи повинні бути позбавлені можливості оскарження рішень, які не зачіпають їхні права.

Суттєвою гарантією забезпечення відкритості та змагальності судового процесу є публічність розгляду справи судом, що передбачає вільний доступ до зали судового засідання, де розглядається справа, громадськості та засобів масової інформації, що висвітлюють перебіг судового процесу, а також вільний доступ до текстів судових рішень.

У справі «Аксьок проти Німеччини» (1983) ЕСПЛ визначив мету відкритого судочинства, зазначивши, що публічний характер процесу допомагає забезпечити справедливе судочинство шляхом захисту учасників процесу від необгрунтованих рішень і дає змогу суспільству контролювати відправлення правосуддя. Разом із публічним проголошенням рішення, публічний характер засідань слугує забезпеченню належного інформування суспільства, у першу чергу через засоби масової інформації та через контроль з боку суспільства за судовим процесом. Обмеження права громадськості та преси бути присутніми під час судового розгляду справи вважається можливим лише в разі необхідності захисту моралі, громадського порядку та національної безпеки, а також, 
якщо цього вимагають інтереси неповнолітніх дітей та потреба захисту приватного життя сторін (рішення в справах «Дінне проти Франції» (1995), Бєляшев проти Росії (2007), «В. та Р. проти Сполученого Королівства» (2001)).

Таким чином, ЕСПЛ визначив правову позицію, за якою відкритий розгляд справи є запорукою довіри суспільства до суду та правосуддя. Водночас ЄСПЛ погодився з тим, що право на публічний розгляд справи може мати певні обмеження на стадії апеляційного та касаційного перегляду справи (рішення у справі «Петренко проти Молдови» (2010)).

Складовим елементом відкритого розгляду справи є публічне проголошення судового рішення. Проте ЄСПЛ стоїть на позиції, що право на публічне проголошення рішення не вважається порушеним, якщо судом проголошено лише резолютивна частина рішення (ухвала у справі «Крочіані та інші проти Італії (1980)).

У рішенні по справі «Хірвісаарі проти Фінляндії» (2001) ЄСПЛ вказав на обов'язок національних судів достатнім чином мотивувати свої рішення, щоб у такий спосіб засвідчити, що сторони були почуті судом, та щоб забезпечити нагляд громадськості за процесом здійснення правосуддя. В іншій справі (Серявін та інші проти України (2010)) ЕСПЛ зазначив, що хоча національний суд й має певну свободу розсуду щодо вибору аргументів у тій чи іншій справі та прийняття доказів на підтвердження позицій сторони, він зобов'язаний наводити обгрунтування своїх рішень. Призначення обгрунтованого рішення полягає в тому, щоб продемонструвати сторонам, що вони були почуті. Крім того, вмотивоване рішення дає стороні можливість оскаржити його та отримати його перегляд вищою інстанцією. Лише за умови винесення обгрунтованого рішення може забезпечуватись публічний контроль здійснення правосуддя.

Важливим елементом фактичного доступу до правосуддя є забезпечення права на апеляційне та касаційне оскарження рішення.

Виконання судового рішення, що набрало законної сили, у практиці ЄСПЛ розглядається як завершальна стадія судочинства, де, власне, й відбувається фактичне поновлення порушених прав особи.

У справах «Горнсбі проти Греції» (1997), «Іммобільяре проти Італії» (1999) та «Войтенко проти України» (2004) Суд вказав, що право на звернення до суду було б ілюзорним, якби національна правова система Договірної сторони дозволяла, щоб остаточне, обов'язкове для виконання судове рішення залишалося невиконаним на шкоду одній із сторін. «...Важко уявити ситуацію, що пункт 1 статті 6 докладно описував процедурні гарантії, що надаються сторонам цивільного судового процесу - у провадженні, що є справедливим, відкритим i оперативним - i не передбачав при цьому гарантій виконання судових рішень; тлумачення статті 6 як такої, що стосується виключно права на звернення до суду і проведення судового розгляду, могло б призвести до ситуацій, несумісних із принципом верховенства права, що його Договірні Сторони зобов'язалися дотримуватися, коли ратифікували Конвенцію. Отже, виконання рішення винесеного будь-яким судом, має розглядатися як невід'ємна частина «судового процесу» для цілей статті 6».

Слід зазначити, що в розумінні ст. 6 Конвенції право на доступ до суду не є абсолютним і може підлягати обмеженню. Вказаний висновок випливає з рішення у справі «Голдер проти Сполученого Королівства», у якому ЄСПЛ вказав, що право доступу до суду за своєю природою вимагає регулюванню з боку держави, яке може змінюватися залежно від часу і місця та відповідно до потреб і можливостей суспільства та окремих осіб. Запроваджуючи таке регулювання, Договірні сторони користуються певними межами самостійного оцінювання, однак застосовані обмеження не можуть звужувати рамок визначеного доступу до суду в такий спосіб чи такою мірою, щоб це зашкодило самій суті права, до того ж буде непропорційним поставленій меті.

Інші акти європейського права, що не є обов'язковими для виконання і належать до джерел «м'якого права», зокрема Рекомендації Комітету Міністрів Ради Европи щодо заходів, що полегшують доступ до правосуддя від 14.05.1981 № $\mathrm{R}(81)$ [6], визначають такі принци доступу до суду як інформування громадськості про місцезнаходження і компетенцію судів, а також про порядок звернення до суду за захистом своїх інтересів, про діючі процесуальні норми та засоби виконання рішення суду; вжиття заходів для максимального скорочення термінів винесення судових 
рішень; визначення розумного розміру судових витрат, який не становитиме перешкоди в доступі до правосуддя.

У Рекомендаціях Комітету Міністрів Ради Європи щодо введення в дію та поліпшення функціонування систем і процедур оскарження у цивільних і торговельних справах від 07.02.1995 № R(95)5 ефективною та найдоступнішою визнано триланкову систему судочинства, яка передбачає можливість оскарження судового рішення, водночас запобігає зловживанню особою цим правом і зменшує навантаження на суди [7].

У Рекомендаціях Комітету Міністрів Ради Європи щодо примусового виконання рішень від 09.09.2003 № Rec(2003)17 вказується на те, що процедури примусового виконання рішень повинні базуватися на нормах національного законодавства і бути якомога дієвішими та ефективнішими; держави мають створити механізм попередження випадків зловживання процедурою виконання рішень однією зі сторін, який не повинен розглядатися як перегляд справи; примусове виконання не має відкладатися, якщо для цього немає законодавчих підстав. Процедура примусового виконання повинна бути чітко визначеною і передбачати ефективні засоби виконання та протидії зловживанню сторонами своїми правами [8].

Висновки. Проведене дослідження дає змогу дійти висновку, що термін «доступ до суду» $€$ комплексною правовою категорією; в ії̈ основі лежать базові критерії, одночасне забезпечення яких гарантує реальне дотримання права особи на доступ до правосуддя, зокрема:

1) фінансовий, що передбачає обов'язок держави встановлення алгоритму визначення розміру судових витрат, який враховує майновий стан учасника справи та не створює перешкоди для реалізації особою самого права звернення до суду, водночас й виконує роль запобіжника зловживання правом звернення до суду.

У тих випадках, якщо особа, яка здійснює підприємницьку діяльність, потребує правничої допомоги і належить до категорії соціально незахищених громадян, національне законодавство повинно передбачати механізм забезпечення такої особи професійною правничою допомогою адвоката за рахунок держави;
2) територіальний - передбачає, що система судів загальної юрисдикції повинна будуватися з урахуванням територіального устрою держави, а місцеві суди, які розглядають усі справи як суди першої інстанції, повинні бути територіально максимально наближені до людини.

Відносно України доцільним уявляється розташування місцевих загальних судів у кожному районному центрі, а місцевих господарських та адміністративних судів - у кожному обласному центрі держави;

3) організаційний - передбачає оптимальну організацію системи судоустрою, що є простою і водночас зрозумілою та ефективною в контексті доступу до суду та процедури захисту прав особи. Для України найоптимальнішою є триланкова система судоустрою.

Крім того, як система загальних судів загалом, так і кожний окремий суд загальної юрисдикції повинні бути створені та здійснювати свою процесуальну діяльність у чіткій відповідності із національним законом.

4) інформаційний, за яким кожна держава повинна на законодавчому рівні закріпити інформування своїх громадян і суб'єктів господарювання про порядок звернення до суду, про умови забезпечення окремих категорій соціально незахищених громадян професійною правничою допомогою, яку надають адвокати за рахунок держави, а також про чинні процесуальні норми;

5) процесуальний, який гарантує здійснення правосуддя на засадах верховенства права, а також неупередженість і безсторонність суду та суддів, розумність строків розгляду справи судом, публічність розгляду справи та проголошення судового рішення, належне мотивування та обгрунтування судового рішення, забезпечення реального виконання судового рішення та повага до остаточного судового рішення;

6) якості законодавства, який покладає на державу обов'язок ухвалення законодавчих актів, що відповідають вимогам доступності та передбачуваності, щоб кожна особа мала змогу отримати адекватну інформацію про обставини застосування правових норм у конкретному випадку. 


\section{СПИСОК ЛІТЕРАТУРИ}

1. Перетворення нашого світу: Порядок денний у сфері сталого розвитку до 2030 року: Резолюція Генеральної Асамблеї Організації Об'єднаних Націй від 25.09 2015. URL: http://sdg.org.ua/ua/resources-2/344-2030-2015 (дата звернення: 09.03.2020).

2. Цілі сталого розвитку: Україна: Національна доповідь. Міністерство економічного розвитку і торгівлі України, 2017. 174 c. URL: http://un.org.ua/images/SDGs_NationalReportUA_Web_1.pdf (дата звернення: 10.02.2020).

3. Загальна декларація прав людини від 10.12.1948. URL: https://zakon.rada.gov.ua/laws/show/995_015 (дата звернення: 09.03.2020).

4. Міжнародний пакт про громадянські й політичні права від 16.12.1966. URL: https://zakon.rada.gov.ua/laws/ show/995_043 (дата звернення: 09.03.2020).

5. Свропейська конвенція про захист прав людини і основоположних свобод від 04.11.1950. URL: https://zakon. rada.gov.ua/laws/show/995_004 (дата звернення: 09.03.2020).

6. Рекомендації Комітету Міністрів Ради Європи щодо заходів, що полегшують доступ до правосуддя, від 14.05.1981 № R(81). URL: https://zakon.rada.gov.ua/laws/show/994_133 (дата звернення: 09.03.2020).

7. Рекомендації Комітету Міністрів Ради Свропи щодо введення в дію та поліпшення функціонування систем $і$ процедур оскарження у цивільних і торговельних справах від 07.02.1995 № R(95)5. URL: https://zakon.rada. gov.ua/laws/show/994_153 (дата звернення: 09.03.2020).

8. Рекомендації Комітету Міністрів Ради Свропи щодо примусового виконання від 09.09.2003 № Rec(2003)17. URL: https://zakon.rada.gov.ua/laws/show/994_868 (дата звернення: 09.03.2020).

Надійшла 11.04.2020

\section{REFERENCES}

1. Peretvorennia nashoho svitu: Poriadok dennyi u sferi staloho rozvytku do 2030 roku: Rezoliutsiia Heneralnoi Asamblei Orhanizatsii Obiednanykh Natsii vid 25.09 2015. URL: http://sdg.org.ua/ua/resources-2/344-2030-2015 [in Ukrainian].

2. Tsili staloho rozvytku: Ukraina: Natsionalna dopovid. Ministerstvo ekonomichnoho rozvytku i torhivli Ukrainy, 2017. 174 p. URL: http://un.org.ua/images/SDGs_NationalReportUA_Web_1.pdf [in Ukrainian].

3. Zahalna deklaratsiia prav liudyny vid 10.12.1948. URL: https://zakon.rada.gov.ua/laws/show/995_015 [in Ukrainian].

4. Mizhnarodnyi pakt pro hromadianski y politychni prava vid 16.12.1966. URL: https://zakon.rada.gov.ua/laws/ show/995_043 [in Ukrainian].

5. Yevropeiska konventsiia pro zakhyst prav liudyny i osnovopolozhnykh svobod vid 04.11.1950. URL: https://zakon. rada.gov.ua/laws/show/995_004 [in Ukrainian].

6. Rekomendatsii Komitetu Ministriv Rady Yevropy shchodo zakhodiv, shcho polehshuiut dostup do pravosuddia vid 14.05.1981 No. R(81). URL: https://zakon.rada.gov.ua/laws/show/994_133 [in Ukrainian].

7. Rekomendatsii Komitetu Ministriv Rady Yevropy shchodo vvedennia v diiu ta polipshennia funktsionuvannia system i protsedur oskarzhennia u tsyvilnykh i torhovelnykh spravakh vid 07.02.1995 No. R(95)5. URL: https://zakon. rada.gov.ua/laws/show/994_153 [in Ukrainian].

8. Rekomendatsii Komitetu Ministriv Rady Yevropy shchodo prymusovoho vykonannia vid 09.09.2003 No. Rec(2003)17. URL: https://zakon.rada.gov.ua/laws/show/994_868 [in Ukrainian].

Received 11.04.2020

\section{V.O. Koverznev}

State Organization "V. Mamutov Institute of Economic and Legal Research of NAS of Ukraine", Kyiv, Ukraine orcid.org/0000-0003-4228-1368

\section{INTERNATIONAL STANDARDS FOR ENSURING THE RIGHT OF ACCESS TO COURT FOR PARTICIPANTS OF ECONOMIC RELATIONS}

Transformation and sustainable development of modern countries is not possible without providing all participants in economic relations with equal access to justice, which should be based on respect for fundamental rights, the Rule of Law, transparent courts and the effective administration of justice, guaranteeing public access to information about activity of commercial courts.

The term "access to court" is a complex legal category based on several basic criteria, the simultaneous provision of which guarantees the actual observance of a person's right to access to justice, in particular:

1) financial, which provides for the obligation of the state to establish such an algorithm for determining the amount of court costs, which takes into account the property of the party and does not create obstacles to the exercise of the right to go to court, while acting as a safeguard against abuse of the right to go to; 
2) territorial, which provides that the system of courts of general jurisdiction should be built taking into account the territorial structure of the state, with local courts, which consider all cases as courts of first instance, should be territorially as close as possible to the person;

3) organizational - provides for the optimal organization of the judicial system, which should be simple and, at the same time, clear and effective, in the context of access to court and the procedure for protection of individual rights. In addition, both the system of general courts as a whole and each individual court of general jurisdiction must be established and carry out their procedural activities in strict accordance with national law;

4) informational, according to which each state must legislate to inform its citizens and business entities about the procedure for going to court, about the conditions of providing certain categories of socially vulnerable citizens engaged in business activities, professional legal assistance provided by lawyers at the expense of the state, as well as the current procedural rules;

5) procedural, which guarantees the administration of justice on the basis of the Rule of Law, as well as impartiality and impartiality of the court and judges, reasonable timeliness of court proceedings, publicity of proceedings and promulgation of court decisions, proper motivation and justification of court decisions, ensuring effective execution of court decisions and respect for final court decision;

6) quality of legislation, which imposes on the state the obligation to adopt legislation that meets the requirements of accessibility and predictability, so that each person has the opportunity to obtain adequate information about the circumstances of the application of legal norms in a particular case.

Keywords: access to justice, justice, Rule of Law, protection of individual rights. 